\title{
Patent rights: once more around the block
}

WhO is entitled to the rewards of a scientific experiment that results in a technological moneyspinner? The research worker involved? His or her supporting institution? The entrepreneur who provides capital to bring the product to the market place? Or the government agency who supported the research? The debate is not newindeed it has been going on for at least 30 years, ever since the rapid post-war expansion of federally sponsored research in universities which is now estimated to be worth over $\$ 3.5$ billion a year.

The latest round of skirmishing has been sparked off by the recent publication of a planned change in federal regulations. It proposes that universities should, under certain defined circumstances, be automatically granted the patent rights to the results of research carried out on government funds.

At present, different government agencies have different policies on patent rights. The Department of Energy, for example, has inherited from the Atomic Energy Commission a statutory 'title' to the rights on research that it has paid for, although it can decide to waive this right and give it to the university which has carried out the research.

In contrast, the Department of Health, Education and Welfare has no statutory responsibilities, but as a matter of policy is prepared to waive rights if a petition to do so is received. Partly as a result of administrative problems in pursuing this policy (last summer, as part of a review of patent policy, a block was put on further waivers holding up about 30 patents which universities had applied for) the department also has a scheme of institutional patent agreements (IPAS). Any institution which receives new research funds can apply for such an agreement. To qualify, the institution has to demonstrate that it operates an effective technology transfer programme. The IPA, if granted, provides that the institution will automatically receive the patent rights on the research it carries out.

At present the only other agency to use IPAS is the National Science Foundation which has agreed them with 19 universities since 1974. Under the new proposals, a revised form of IPA would be extended to all government agencies sponsoring university research, and would become the standard mechanism for dealing with patent rights.

Both the universities and the agencies are, in general, in favour of

\author{
David Dickson reports on the \\ latest skirmishing in the US \\ over who should get rich out \\ of money-spinning inventions
}

this scheme. Despite reservations on details, both see it not only as a way of cutting down administrative paperwork and promoting standardised procedures, but also as encouraging the transfer of technology to private industry.

What has concerned others, however, and has in particular attracted the attention of the Monopoly and Anti-competitive Activities Subcommittee of Senator Gaylord Nelson's Select Committee on Small Business, is whether, by allowing universities such cational associations recently, for example, $\mathrm{Dr}$ Thomas Jones, vicepresident for research at Massachusetts Institute of Technology, said that the total university income from patent royalties was only about $\$ 9$ million a year, and that few universities operated licencing programmes in the black.

It was also made clear by Dr Jones, however, that the gain to universities of negotiating licences directly with private industry is not primarily financial, but that such practices help to establish links between the two sectors. Industry is more prepared to collaborate with a university if it can be sure that the results of research will be available for licencing.

The universities will have a further chance to argue their case at a second series of hearings planned by the sub-

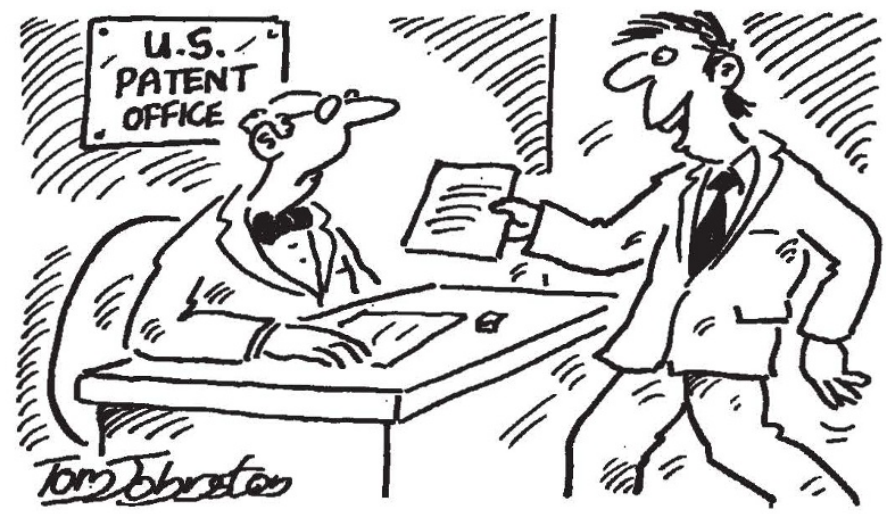

rights, the government is giving away more than is in "the public interest" considering the size of its expenditure on university research. Ralph Nader's health research group, for example, in a move which led to the temporary postponement of the implementation of the new regulations, complained to the General Services Agency that the regulations would permit universities and commercial enterprises to "reap hundreds of millions of dollars of profits from work supported by the federal government". In particular such arguments have recently been made about research involving recombinant DNA techniques, for which Dr Donald Fredrickson, Director of the National Institutes of Health, subsequently decided that no exemption from the standard IPA procedure need be made.

Universities dispute the allegations that patent licencing denies the federal government a major source of income. In particular they claim that the financial benefits received as royalties from the licencing of patents is often much lower than imagined. Addressing hearings of the Senate Subcommittee on behalf of a wide range of edu- committee for 20,21 and 26 June. These hearings are expected to focus on ways in which the subcommittee feels that the proposed IPAs would be more liberal than those currently in force.

Two issues in particular have already attracted the attention of the subcommittee, which is at present carrying out a two year study of federal patent policy. The first is the amount of time for which a university will be permitted to grant exclusive licence to a manufacturer who is only prepared to undertake production on this basis. At present, exclusive licences can be granted for a period of eight years, or three years from the date of first sale of a product, whichever is the shorter. Under the new regulations, the three years would be extended to five, and allowance would also be made for time taken by a regulatory agency to make its pre-market clearance.

The universities argue that they must be able to maximise the attraction of a particular patent to a potential investor. "Market development costs are often much greater than the physical cost of invention. Private 
enterprise therefore has to be given some incentive in order to be confident of a reasonable profit", according to $\mathrm{Mr}$ William Bremer of Wisconsin University.

The Senate Subcommittee, however, has expressed concern at the 'monopoly' effect of issuing exclusive licences. It claims that although under both the present and projected form of the IPA, these are intended to be the exception rather than the rule, in practice most licences are granted on such a basis. A second concern is over who should decide whether a research worker should be granted a licence to develop a discovery he has made. In the initial draft of the new regulations, it was suggested that, in line with current practice at the NSF, this would require the agreement of the agency which had sponsored the research.

When this draft was sent out for comment, however, many universities reacted strongly against it, claiming that it would reduce the incentive for the individual research worker to report a potentially patentable discovery. The provision has now been dropped from the proposed regulations, raising the subcommittee's concern that universities may offer exclusive licences to a research worker rather than seeking outside, more appropriate, licensees.

Are there any alternatives to IPAs? William Carey, executive officer of the American Association for the Advancement of Science, together with others, feels that they should be dropped altogether as an unnecessary impedance on the flow of scientific ideas into the technological marketplace.

Subcommittee staff members are also looking at the possible appropriateness of a government agency such as the UK's National Research Development Corporation, which has a statutory responsibility to handle the patenting and licencing aspects of research carried out on government money including that funded in universities by the UK's research councils.

But at present any major innovation in patent policy, apart from the introduction of the new regulations, seems unlikely. Recognising the complexity of the issues-economic, political and legal-and the intensity of the motions that they raise the White House, for example, has steered clear of the area and it will not be part of a multiagency study of innovation announced recently. "The debate over government patent policy is a thicket a prudent man hesitates to enter," Mr Charles H. Herz, general counsel of the NSF, told the Senate Subcommittee. So it has been--and so it promises to remain.

David Dickson

\section{Friedrich Wöhler RIP}

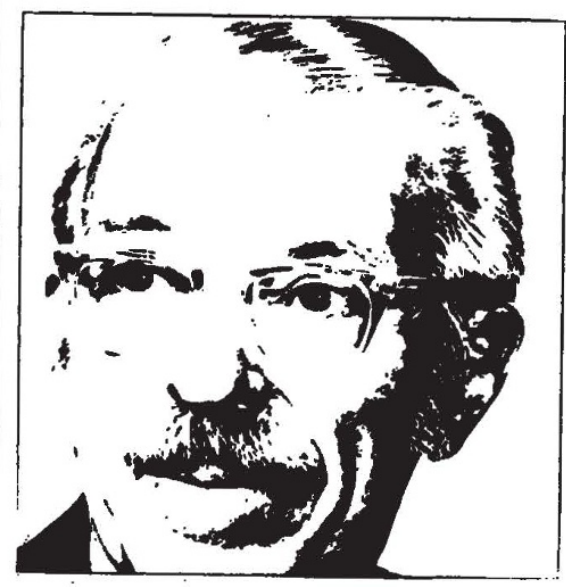

\section{THOMAS H. JUKES}

THIs year is the sesquicentennial of the announcement by Wöhler that marked the birth of synthetic organic chemistry. Earlier, Berzelius had formulated a concept that the numerous carbon compounds found in natural sources could be produced only by living organisms. "Elements in the organic world," said he, "appear to obey laws different from those in the inorganic world." His concept was the molecular equivalent of the dogma of spontaneous generation of life, a theory that had been put to death by the Abbé Spallanzani in the eighteenth century. As a result, the theory was, as Voltaire said, "rejected by whoever has studied nature at all". In like manner, Wöhler refuted Berzelius' theory by preparing urea from ammonia and carbon dioxide. In a sense, Berzelius' 'organic' chemistry was no longer organic. But the name persisted, and, as everyone except 'organic food' cultists should know, the term 'organic' properly refers to carbon compounds rather than to vegetables grown with the aid of animal manure.

The vitalists were not extinguished by Spallanzani, and, despite Voltaire's dismissal of their cause, they returned in 1858 to proclaim that spontaneous generation of animals and plants could be demonstrated in the laboratory. Pasteur promptly turned back their challenge with a series of famous experiments. One would have thought that, by 1978 , Wöhler's discovery would have convinced everyone that 'natural' compounds can be synthesized. But mythology is more persistent than veracity. Even the use of Wöhler's own compound, synthetic urea, which is used as a fertilizer, is challenged as not being equivalent to animal excreta for this purpose. The challengers have something to sell-a line of 'natural food' products. The selling job has been so pervasive that an extensive opinion survey in 1972 showed that $65 \%$ of the general public, and $52 \%$ of college graduates said "No" to the question, "Are man-made vitamins just as good as natural vitamins?"

Recently, at a meeting, when I pointed out that a synthetic vitamin is identical with its natural counterpart, a prominent Washington Post reporter said, "Your colleagues don't agree with you". To which I responded that, in this case, my colleagues would be wrong, and I asked her if she had ever heard of a mixed melting point. Of course she had not, and she was obviously not interested in my attempt to obfuscate the discussion by trotting out such scientific jargon.

'Natural', in terms of food, means a blessed surcease from hyperactivity in children, according to true believers. The proponent of this belief, Dr Ben Feingold, tells his followers that the statement "that the whole body is chemical; that all components of food are chemical" is "a somewhat ridiculous public relations argument of the additive industry," also that "not a single one of the synthetics used in our food has been subjected to the rigid investigations required for licencing drugs," which is quite untrue, because synthetic vitamins are used in both foods and drugs. The dietary treatment that he prescribes is based on elimination and exclusion of synthetic substances from the list of permitted foods. This procedure is a curious echo of the ancient ritualistic casting-out of demons from those who were possessed (and therefore hyperactive).

And 'natural' means profits. An officer of the Federal Trade Commission wrote recently of manufacturers who "do have a deep concern with their right to describe products as natural under the conditions described". I suspect that this deep concern may be connected with hope of sales. A vice-president of a large food company told me last month of his company's plans to test-market a new breakfast cereal which, he said, would be really natural, and contain "only natural vitamins". My attention wavered, and then vanished. But perhaps I should send him a copy of Ann. Physik. 12, 253 (1828) so that he can read about making urea without kidney, bladder, or lamp-post-seeking possessor thereof. 